\title{
Editorial
}

\section{The Improvisation of Human Experience: Joseph J. Branin (1947-2012)}

\author{
"There's nothing that makes you so \\ aware of the improvisation of human \\ experience as a song unfinished." \\ Carson McCullers, \\ "The Sojourner" (1950) ${ }^{1}$
}

It is in the nature of our work that we often must leave it unfinished. No catalog record has ever fully captured the richness of its subject, and no collection is ever complete. The library building has not been built that could not benefit from additional features, and no one has left my reference desk or classroom without me wondering if I could not have provided her with one more citation or helped him to master one more concept. The quest for the ideal search-and-discovery system continues in the age of the Semantic Web with the same zeal that it did in the age of Melvil Dewey. We librarians come to our work knowing that we must build on the services, systems, collections, and relationships established by those who came before us, and we leave that work excited to see how it will grow after we are gone. And, sometimes, we leave it too soon. So it was for our colleague, Joseph J. Branin, editor of College $\mathcal{E}$ Research Libraries from 2007 until his untimely death in December. He left us an important legacy and he left it too soon.

Even without Joe's death last year, this would have been a time for reflection at College $\mathcal{E}$ Research Libraries as 2013 marks the final year of print publication for a journal that began in 1939 with an editorial that asked, "why another library journal?"2 Over the succeeding 74 volumes, CERL editors, authors, and readers answered that question by presenting the results of research that helped to ensure that libraries remained at the heart of the academy during a century of unprecedented and unceasing change in librarianship, information technology, scientific inquiry, popular and scholarly publishing, and higher education around the world. Together, we built a community of data-informed practice that has shaped the libraries, information centers, campuses, and virtual spaces where we work. Even now, members of the CERL editorial staff are working with the ACRL $75^{\text {th }}$ Anniversary Task Force to determine how best to commemorate the definition and promotion of the literature of academic and research librarianship as a key component of the Association's history. Others are working with you, our readers and authors, to determine how $C \mathcal{E} R L$ will continue to play a central role in your work once we have completed the transition to a wholly-digital publishing platform. Perhaps we will begin volume 75 with a nod to our past by titling our first editorial, "Re-Introducing College and Research Libraries: Why Another Electronic Library Journal?"

Whatever we do with this journal that we have shared for as long as any of us have been librarians, we will owe a debt to Joe Branin. Joe did not "make" College $\mathcal{E}$ Research Libraries, which has been a leading journal in our field for decades, but he encouraged us not to rest on our laurels and he forced us to confront the difficult questions facing all scholarly journals in the age of digital publishing. It was on Joe's watch that we embraced the principles of open access that many 
of us have promoted for years on our campuses as part of the broader discussion of scholarly communications. It was on Joe's watch, too, that we expanded the pool of peer reviewers and editors who ensure the quality of the work we publish and who foster engagement among our readers and authors. And it was on Joe's watch that a more vibrant community of Library \& Information Science editors began to meet routinely and to present panels at conference in order to support new authors, to promote best practices in scholarly publishing in our field, and to engage the broader community of scholarly journal editors. Finally, it was on Joe's watch that we made the commitment to ensuring the continued quality of the scholarship presented in this journal while also exploring what it means to be a "gateway" to scholarship and scholarly community in the digital age.

As I consider our good friend's legacy and the work we must do together to build upon it, I remember the words of St. Vincent de Paul, whose name graces the institution where I am now employed: "...there are two things to be considered here, namely not only to do good, but to do it well." 3 Joseph J. Branin did so much good, as a colleague, a mentor, a library leader, and as our editor, and he did it so well. He left us too soon, his work unfinished, but together we can build on it, and so do our part to honor his memory.

\section{Notes}

1. Carson McCullers, "The Sojourner," in The Ballad of the Sad Café: The Novels and Stories of Carson McCullers, p. 112 . Boston: Houghton Mifflin, 1951.

2. A. F. Kuhlman, "Introducing College \& Research Libraries," College \& Research Libraries 1, no. 1 (1939): 7-10, accessed January 8, 2013, http://crl.acrl.org/content/1/1/7.full.pdf+html.

3. "What Did Vincent Say?," DePaul University, accessed January 8, 2013, http://topaz.cstcis. cti.depaul.edu/quotes/quotes/809.

\section{Errata}

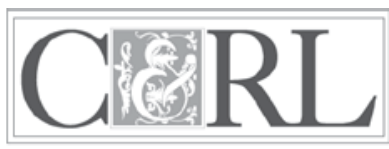

The guest editorial from Scott Walter entitled "An Embarrassment of Riches: Ethics and Scholarly Publishing in the Digital Environment," which originally appeared in the November 2012 issue was mistakenly rerun in the January 2013 issue. It has since been removed from the online version of the January 2013 issue and appears only in the November 2012 issue.

We regret the error. 